\section{Tergitol-TMN-6 Surfactant Is an Effective Blossom Thinner for Stone Fruits}

\author{
Esmaeil Fallahi' ${ }^{1,9}$ and Bahar Fallahi ${ }^{2}$ \\ Department of Plant, Soil, and Entomological Sciences, Parma Research and \\ Extension Center, University of Idaho, 29603 U of I Lane, Parma, ID 83660
}

\section{James R. McFerson ${ }^{3}$ \\ Washington Tree Fruit Research Commission, 1719 Springwater, \\ Wenatchee, WA 98801}

\author{
Ross E. Byers ${ }^{4}$ \\ Virginia Tech-AREC, 595 Laurel Grove Road, Winchester, VA 22602
}

\begin{abstract}
Robert C. Ebel, ${ }^{5}$ Robert T. Boozer, ${ }^{6}$ Jim Pitts, ${ }^{7}$ and Bryan S. Wilkins ${ }^{8}$ Department of Horticulture, Auburn University, 101 Funchess Hall, Auburn, AL 36849
\end{abstract}

Additional index words. Crop load, fruit set, peaches, plums, nectarines, Prunus domestica, Prunus persica, 2,6,8-trimethyl-4-nonyloxypolyethyleneoxyethanol

\begin{abstract}
Effects of Tergitol-TMN-6 surfactant on blossom thinning (fruit set), fruit quality, and yield were studied in different cultivars of peach (Prunus persica [L.] Batsch) during 2003 to 2005, and in one cultivar of nectarine Prunus persica [L.] in one orchard and one cultivar of plum (Prunus domestica [L.]) in two orchards in 2004. In addition to Tergitol-TMN-6, effects of Crocker's fish oil (CFO) alone in three peach cultivars or in combination with lime sulfur in a nectarine cultivar were studied on fruit set, quality, and yield. Tergitol-TMN-6 at $5 \mathrm{~mL} \cdot \mathrm{L}^{-1}$ or higher rates, applied at about $75 \%$ to $85 \%$ bloom, reduced fruit set without russeting peach fruit. Peach fruit size was often increased by Tergitol-TMN-6 treatment. Applications of Tergitol at $20 \mathrm{~mL} \cdot \mathrm{L}^{-1}$ or $30 \mathrm{~mL} \cdot \mathrm{L}^{-1}$ excessively thinned peaches. Tergitol-TMN-6 at all rates burned foliage, but the symptoms disappeared after a few weeks without any adverse effects on tree productivity. Tergitol-TMN-6 at $7.5 \mathrm{~mL} \cdot \mathrm{L}^{-1}$ or $10 \mathrm{~mL} \cdot \mathrm{L}^{-1}$, applied either once at about $80 \%$ to $85 \%$ bloom or twice at $35 \%$ bloom and again at $80 \%$ to $85 \%$ bloom, reduced fruit set without any fruit russeting in nectarine. Tergitol-TMN-6 at $7.5 \mathrm{~mL} \cdot \mathrm{L}^{-1}$ to $12.5 \mathrm{~mL} \cdot \mathrm{L}^{-1}$ reduced fruit set in 'Empress' plum. CFO at $30 \mathrm{~mL} \cdot \mathrm{L}^{-1}$ was effective in blossom thinning of some peach cultivars. A combination of lime sulfur and CFO was not effective in blossom thinning of nectarine. Considering results from several orchards in different locations in the Pacific Northwest over 3 years, Tergitol-TMN-6 is an excellent blossom thinner for peach, nectarine, and plum at rates of 7.5 to $12.5 \mathrm{~mL} \cdot \mathrm{L}^{-1}$, sprayed at a spray volume of $1870.8 \mathrm{~L} \cdot \mathrm{ha}^{-1}$ when about $75 \%$ to $85 \%$ blooms are open.
\end{abstract}

Early thinning of stone fruit and apples is important because of its impact on fruit size (Fallahi, 1997; Fallahi et al., 1997). Many blossom thinners are caustic, and reduce fruit

Received for publication 15 Feb. 2006. Accepted for publication 27 Apr. 2006.

${ }^{1}$ Professor and Research Director of Pomology.

${ }^{2}$ Research Associate of Pomology.

${ }^{3}$ Manager, Washington Tree Fruit Research Commission.

${ }^{4}$ Emeritus Professor of Pomology.

${ }^{5}$ Associate Professor of Horticulture.

${ }^{6}$ Area Horticulturist.

${ }^{7}$ Superintendent, Chilton Area Research and Extension Center, Thorsby, Alabama.

${ }^{8}$ Field Research Associate.

${ }^{9}$ To whom correspondence should be addressed; e-mail efallahi@uidaho.edu

The authors express their appreciation to the Washington Tree Fruit Research Commission Stone Fruit Group, Idaho Stone Fruit Committee, and Utah Fruit association for their financial support of this project. significantly reduced fruit set in 'Flavorcrest' peach (Fallahi et al., 1998). Dormex was a more consistent blossom thinner for apple and peach than monocarbamide dihydrogen sulfate or sulfcarbamide (Wilthin, 79\% a.i.), 7, oxybicylo(2,2,2) heptane-2-3 dicarboxcylic acid (Endothall, 0.5\% a.i.; an aquatic herbicide), and pelargonic acid (Thinex) (Fallahi, 1997; Fallahi et al., 1997). In field trials in Washington, California, and Idaho, Endothall was an effective blossom thinner for apples and stone fruit (Fallahi, 1997; Warner, 1998). Fallahi (1997) reported that Endothall effectively thinned 'Redhaven' peach blossoms at a rate of $1.87 \mathrm{~mL} \cdot \mathrm{L}^{-1}$ formulation when $85 \%$ to $90 \%$ of blooms were open. However, Endothall was ineffective when applied at $100 \%$ bloom, when most flowers were already fertilized. Wilthin has been used for blossom thinning in stone fruit, including peaches (Fallahi, 1998; Greene et al., 2001; Warner, 1998) and plums (Fallahi, 1998). On 'Friar' plum, full-bloom application of Wilthin at $10 \mathrm{~mL} \cdot \mathrm{L}^{-1}$ plus polyoxyethylenepolypropoxypropanol (Regulaid with $90.6 \%$ a.i) at $1.25 \mathrm{~mL} \cdot \mathrm{L}^{-1}$, using a hand-gun sprayer, increased fruit size (Fallahi and Willemsen, 2002). In a comparison of ammonium thio sulfate (ATS), Wilthin, and Endothall, it was found that ATS was the best blossom thinner under Washington conditions (Warner, 1998). In that report, however, fruits from ATS-treated trees remained small. Blossom thinning of sweet cherry (Prunus avium L.) with ATS and Crocker's fish oil (CFO) is becoming extremely important because newly developed dwarf rootstocks may result in smaller fruits if the crop is not thinned, and scientists in Washington are leading this field of research. Whiting and colleagues (2006) reported that a double application of ATS or CFO, once at $10 \%$ bloom and again at $90 \%$ bloom, significantly reduced fruit set on 'Bing' cherry in 2 years under conditions of central Washington. Full-bloom application of the surfactant N, N-bis2-(omegahydroxypolyoxyethylenepoly-oxypropylene) ethyl alkylamine (Armothin) at $30 \mathrm{~mL} \cdot \mathrm{L}^{-1}$ or $5 \mathrm{~mL} \cdot \mathrm{L}^{-1}$ reduced fruit set in 'Loadel' peach in California (Southwick et al., 1998).

Byers and Lyons (1985) reported that Surfactant WK killed peach flowers by killing peduncles and pistils. Thus, the mode of action of this chemical is different from most other caustic thinners that are only toxic to pistils or stamens. Surfactant 2,6,8-trimethyl4-nonyloxypolyethyleneoxyethanol (Tergitol) TMN-6 ( $90 \%$ aq.) was at least one of the putative a.i. of Surfactant WK, a surfactant that was labeled by DOW Chemical Company and available during the 1980s. Wilkins and associates (2004) reported that Tergitol-TMN-6 effectively reduced fruit set in 'Fireprince' peach under climatic conditions of Clanton, Ala. In that report, there was no difference in thinning response at full bloom or petal fall, suggesting a wide window of efficacy for this chemical.

Despite considerable production of stone fruit worldwide, there is no reliable blossom 
thinner available for these fruit crops. Growers spend between $\$ 960$ to $\$ 2600$ per ha for hand thinning of stone fruit (personal knowledge). The increasing cost of fruit production and labor issues in the globally competitive fruit market mandates discovery of a new and reliable blossom thinner for stone fruits. The goal of this study was to determine the efficacy of Tergitol-TMN-6 on blossom thinning, fruit quality, and yield in different cultivars of peaches and one cultivar of nectarine and plum. We have also studied the effects of CFO from Quincy, Wash., on the efficacy of thinning several cultivars of peach.

\section{Materials and Methods}

\section{General experimental design, orchard conditions, and methods}

Several experiments were conducted on peaches (Prunus persica [L.] Batsch) during 2003 through 2005, 'Empress' plum (P. domestica [L.]) in 2004, and 'July Red' nectarine in 2005. The experimental design in all experiments was a randomized complete block design with three blocks. Each block consisted of two adjacent rows, and each row had eight trees per treatment. To avoid contamination (border effect), four trees in the middle of the eight-tree segment per row were selected for sampling, although the entire eight trees received the same treatment. Also, at least two buffer rows were situated between the sets of adjacent experimental rows. Therefore, each treatment had eight trees per block, with total of 24 trees per experiment. Analysis of variance were computed using the statistical package by SAS (Raleigh, N.C.) for all experiments, and means were separated using LSD at the 5\% level. A factorial arrangement and orthogonal contrast analysis were also used in a peach experiment in 2004 and a nectarine experiment in 2005, and is described later. Air blast sprayers were used in all experiments throughout this study. No surfactant was used in any of the experiments in this study.

The planting space and age of trees varied from experiment to experiment, but all trees were on Lovell peach rootstock. All experimental orchards had sandy loam soils with a $\mathrm{pH}$ of about 7.5. Other than the case for the 'Zee Lady' and 'Snow Giant' experiments in 2005 , all trees were pruned to an open-vase shape with four to five main scaffolds. Other than blossom thinning treatments, all other cultural practices in these orchards were similar to those of commercial orchards.

On different sides of each tree, four fruitbearing hangers or branches were randomly selected and tagged at their base. Fruit set was calculated by one or two of the following methods. For method 1, the total number of flower buds on each of the selected hangers was counted about 7 days before bloom (before any treatment application). The total number of fruit on the tagged hangers or branches was counted after "June drop." Fruit set in method 1 was calculated as fruit number/flower number $\times 100$. For method 2 , the diameter of each tagged hanger or branch at its basal point was measured using a digital caliper (Digimatic model CD-6; Mitutoyo, Tokyo, Japan), and the cross-sectional area of that basal point was calculated. The total number of fruit on the tagged hangers or branches was counted after "June drop," just before the "pit-hardening" stage. Fruit set in method 2 was calculated as number of fruit/ cross-sectional area at the basal point. After counting fruits by either method, fruits in all treatments were hand thinned at the beginning of pit hardening to maintain about 13 to $15-\mathrm{cm}$ spacing between fruits. Trees used for the "control" in all experiments did not receive any blossom thinner but received hand thinning as described earlier. These hand-thinned trees are referred to as "control" throughout the article and tables.

Yield per tree for all tested stone fruits was recorded. In all experiments, the final yield in the "control" trees should be considered the targeted crop load and be used for comparison with blossom thinners' responses, because hand thinning alone is currently the standard thinning practice in the stone fruit industry. About 50 fruit per tree were sampled at harvest, cleaned, visually evaluated for russeting (fruit marks), and percentage of fruit russeting was calculated. Thirty of these fruit were used for weight and color measurements. Fruit color was measured by giving a continuous ranking from 1 (green) progressively to 5 (fully developed color). Fruit weight was used as the measure for fruit size.

\section{Experiments in 2003}

In 2003, three commercial orchards in Fruitland, Idaho, and two in Sunny Slope, Idaho, were used for blossom-thinning experiments. Each of these orchards had a different cultivar.

One of the two orchards in Sunny Slope was a 10 -year-old 'Elberta' at $2.7 \times 5.5-\mathrm{m}$ spacing and the other one was a 5-y-old 'August Lady' at $2.4 \times 4.9-\mathrm{m}$ spacing. Both cultivars received the same treatments on 31 Mar. 2003, when trees of 'Elberta' peaches were in about $70 \%$ to $75 \%$ bloom and those in 'August Lady' were about $80 \%$ bloom. The treatments were control, $\mathrm{CFO}$ at $30 \mathrm{~mL} \cdot \mathrm{L}^{-1}$, Tergitol-TMN-6 (90\% aq.) at $5 \mathrm{~mL} \cdot \mathrm{L}^{-1}$, and Tergitol-TMN-6 at 10,20 , or $30 \mathrm{~mL} \cdot \mathrm{L}^{-1}$. All applications were made at a spray volume of $1870.8 \mathrm{~L} \cdot \mathrm{ha}^{-1}$. Trees had no freeze damage before blossom thinning and had heavy bloom and moderately good pollination conditions. During treatment, the weather was calm, sunny, and air temperature was about $21.1^{\circ} \mathrm{C}$ and reached a maximum of $23.8^{\circ} \mathrm{C}$ during that day. Fruit set was calculated based on method 2 for 'Elberta' and 'August Lady' in 2003.

The three orchards in Fruitland were 6year-old trees of 'Red Globe', 'Blazing Star', and 'Redhaven'. The tree spacing in each of these orchards was $2.4 \times 4.9 \mathrm{~m}$. In each cultivar, treatments were control or Tergitol-TMN-6 at $10 \mathrm{~mL} \cdot \mathrm{L}^{-1}$ or $30 \mathrm{~mL} \cdot \mathrm{L}^{-1}$. In addition to these treatments, 'Red Globe' received a fourth treatment of $\mathrm{CFO}$ at 30 $\mathrm{mL} \cdot \mathrm{L}^{-1}$. The experimental orchards in Fruitland were sprayed on 30 Mar. 2003 when trees in 'Red Globe' were at $83 \%$ bloom, 'Redhaven' were at $85 \%$ bloom, and 'Blazing Star' were at $90 \%$ bloom. Trees were sprayed at $1870.8 \mathrm{~L} \cdot \mathrm{ha}^{-1}$. Trees had no freeze damage before blossom thinning and had heavy bloom and excellent pollination and fertilization conditions. During the spray, it was calm, sunny, and air temperature was about $18.3{ }^{\circ} \mathrm{C}$ and reached maximum of $21.1{ }^{\circ} \mathrm{C}$ during that day.

\section{Experiments in 2004}

In 2004, two peach cultivars (in two different orchards) in the Sunny Slope area, and two different orchards of plums in Payette, Idaho, were selected. These orchards were a 6-y-old 'August Lady' at $2.4 \times 4.9 \mathrm{~m}$; a 7-y-old 'Zee Lady' at $2.1 \times 5.5-\mathrm{m}$ spacing; and two orchards, each with 14-y-old trees of 'Empress' plum on plum rootstock, planted at $2.4 \times 4.9-\mathrm{m}$ spacing. The treatments for both peach orchards in 2004 were control and Tergitol-TMN-6 at $5 \mathrm{~mL} \cdot \mathrm{L}^{-1}, 7.5 \mathrm{~mL} \cdot \mathrm{L}^{-1}$, or $10 \mathrm{~mL} \cdot \mathrm{L}^{-1}$. In the 'August Lady' orchard, each rate of Tergitol-TMN-6 was applied at a spray volume of either $935.4 \mathrm{~L} \cdot \mathrm{ha}^{-1}$ or $1870.8 \mathrm{~L} \cdot \mathrm{ha}^{-1}$. In the 'Zee lady' orchard, Tergitol-TMN-6 at each rate was sprayed at a spray volume of $1870.8 \mathrm{~L} \cdot \mathrm{ha}^{-1}$. Trees of 'August Lady' were in about $85 \%$ and those of 'Zee Lady' were in about $75 \%$ bloom at the time of treatment application. Both cultivars were sprayed on 4 Apr. 2004, and temperature at the time of application was about $22.8{ }^{\circ} \mathrm{C}$, reaching a maximum of $26.1{ }^{\circ} \mathrm{C}$, with excellent pollination and fertilization conditions before the blossom thinning. Treatments in 'Empress' plum trees in both orchards were control and Tergitol-TMN-6 at $7.5 \mathrm{~mL} \cdot \mathrm{L}^{-1}, 10 \mathrm{~mL} \cdot \mathrm{L}^{-1}$, or $12.5 \mathrm{~mL} \cdot \mathrm{L}^{-1}$, with each concentration applied at a spray volume of $1870.8 \mathrm{~L} \cdot \mathrm{ha}^{-1}$. Plum trees were sprayed on 7 Apr. 2004, when trees were at about $75 \%$ to $80 \%$ bloom. Temperature at the time of application was about $21.8{ }^{\circ} \mathrm{C}$, reaching a maximum of $25.1^{\circ} \mathrm{C}$, with good pollination and fertilization conditions before blossom thinning.

In 2004, the analysis of data in the 'August Lady' peach experiment was carried out in two ways. Once all treatments, including the control, were analyzed together and the means were separated by LSD. Then only data with three different rates of Tergitol-TMN-6 with two spray volumes $\left(935.4 \mathrm{~L} \cdot \mathrm{ha}^{-1}\right.$ or $1870.8 \mathrm{~L} \cdot \mathrm{ha}^{-1}$ ) were analyzed in a $3 \times 2$ factorial arrangement and orthogonal contrast procedure, and the main effects (rate and spray volume) as well as interaction between rate and spray volume were computed using SAS packages.

\section{Peach experiments in 2005}

Two peach orchards for the 2005 experiments were located at the University of Idaho Parma Research and Extension Center near Parma, Idaho. The trees were planted at $1.8 \times$ 5.0-m spacing and trained to a Y-shape 
system. Treatments for these experiments were control and Tergitol-TMN-6 at 7.5 $\mathrm{mL} \cdot \mathrm{L}^{-1}, 10 \mathrm{~mL} \cdot \mathrm{L}^{-1}$, or $12.5 \mathrm{~mL} \cdot \mathrm{L}^{-1}$, each applied at a spray volume of $1870.8 \mathrm{~L} \cdot \mathrm{ha}^{-1}$ on 5 Apr. 2005. At the time of application, 'Zee Lady' was at $75 \%$ bloom and 'Snow Giant' was at $85 \%$ bloom. It was calm and sunny, with excellent bee activity during blossom thinning, and fertilization conditions were excellent before blossom-thinning application. The temperature during application was about $10.0^{\circ} \mathrm{C}$, and reached a maximum of $14.4{ }^{\circ} \mathrm{C}$ that day. In both 'Zee Lady' and 'Snow Giant' orchards, fruit set was measured based on method 2 .

\section{'July Red' nectarine experiments in 2005}

The orchard was located at Sunny Slope, Idaho, and trees were planted at $3.0 \times 5.5-\mathrm{m}$ spacing. The treatments for this orchard were control; $\mathrm{CFO}$ at $20 \mathrm{~mL} \cdot \mathrm{L}^{-1}$ mixed with lime sulfur at $20 \mathrm{~mL} \cdot \mathrm{L}^{-1}$ applied twice; and Tergitol-TMN-6 at $7.5 \mathrm{~mL} \cdot \mathrm{L}^{-1}$ or $10 \mathrm{~mL} \cdot \mathrm{L}^{-1}$, each rate applied once or twice. Trees that received any blossom thinner treatment twice were sprayed once at $35 \%$ bloom and again at about $80 \%$ to $85 \%$ bloom. Trees receiving one treatment were sprayed when about $80 \%$ to $85 \%$ of blooms were open, with good pollination and fertilization conditions before the application of blossom thinners. The first applications were made when the temperature was about $15.6^{\circ} \mathrm{C}$, reaching a maximum of $17.8{ }^{\circ} \mathrm{C}$ on 2 Apr. 2005. The second applications were made when the temperature was about $13.9^{\circ} \mathrm{C}$, reaching a maximum of $14.4{ }^{\circ} \mathrm{C}$ on 5 Apr. 2005. During 2005, all applications were made at a spray volume of $1870.8 \mathrm{~L} \cdot \mathrm{ha}^{-1}$.

Blossom buds were counted on 30 Mar. 2005 and fruit set was measured based on method 1, as described earlier. Fruits were sampled for quality evaluation on 23 Aug. 2005.
In 2005, the analysis of data in the 'July Red' nectarine experiment was carried out in two ways. Once all treatments, including control, were analyzed together and means were separated by LSD. Then, only data with two different rates of Tergitol-TMN-6 (7.5 $\mathrm{mL} \cdot \mathrm{L}^{-1}$ or $10 \mathrm{~mL} \cdot \mathrm{L}^{-1}$ ) with two frequency of sprays (at $80 \%$ to $85 \%$ bloom or both at $35 \%$ bloom and again at $80 \%$ to $85 \%$ bloom) were analyzed in a $2 \times 2$ factorial arrangement and orthogonal contrast procedure, and the main effects (rate and frequency of spray) as well as interaction between rate and frequency of spray were computed using SAS packages.

\section{Peach experiments in Utah in $\mathbf{2 0 0 5}$}

Eight-year-old trees of 'O'Henry', 'John Henry', and 'Angelus' peaches, each in a different orchard, were selected in Utah during 2005. The tree spacing in all orchards was 2.4 $\times 4.9 \mathrm{~m}$. The treatments for each cultivar were control and Tergitol-TMN-6 at 7.5 $\mathrm{mL} \cdot \mathrm{L}^{-1}, 10 \mathrm{~mL} \cdot \mathrm{L}^{-1}$, or $12.5 \mathrm{~mL} \cdot \mathrm{L}^{-1}$, applied when trees were at about $80 \%$ bloom at a spray volume of $1870.8 \mathrm{~L} \cdot \mathrm{ha}^{-1}$. Temperature during application was about $21.1^{\circ} \mathrm{C}$ and reached a maximum of $23.9{ }^{\circ} \mathrm{C}$ during that day, with good pollination and fertilization conditions before blossom-thinning application. Fruit set in all cultivars tested in Utah was calculated based on method 1 as described earlier.

\section{Results and Discussion}

\section{Experiments in 2003}

In Sunny Slope, Idaho, application of Tergitol-TMN-6 at $5 \mathrm{~mL} \cdot \mathrm{L}^{-1}$ or higher significantly reduced fruit set in both 'Elberta' and 'August Lady' peaches (Table 1). Tergitol-TMN-6 at $10 \mathrm{~mL} \cdot \mathrm{L}^{-1}, 20 \mathrm{~mL} \cdot \mathrm{L}^{-1}$, or 30 $\mathrm{mL} \cdot \mathrm{L}^{-1}$ was excessive and resulted in severe foliar injury, overthinning, and lower yields, and the extent of the effects were proportional to the concentration of this chemical
(Table 1). Within about $2 \mathrm{~h}$ after application of Tergitol-TMN-6, flowers desiccated, turned dry, and wilted. Early-emerged leaves showed tip burning and turned brown. We observed some burning of the tender twigs in the trees receiving very high rates of TergitolTMN-6. Foliage and other injury symptoms recovered after about 4 to 6 weeks.

Application of Tergitol-TMN-6 at $10 \mathrm{~mL} \cdot \mathrm{L}^{-1}$ or $20 \mathrm{~mL} \cdot \mathrm{L}^{-1}$ increased fruit size in both 'Elberta' and 'August Lady' cultivars in 2003; nevertheless, the fruit size increase in these treatments did not bring their yields up to the level of the control trees that were only hand thinned (Table 1). Application of CFO reduced fruit set in 'Elberta' but not in 'August Lady' (Table 1). However, fruit size was unaffected by CFO in either cultivar. None of the treatments caused any symptoms of fruit russeting in either cultivar (Table 1).

In Fruitland, Idaho, Tergitol-TMN-6 at 10 $\mathrm{mL} \cdot \mathrm{L}^{-1}$ or $30 \mathrm{~mL} \cdot \mathrm{L}^{-1}$ reduced fruit set and yield but increased fruit size in 'Red Globe', 'Redhaven', and 'Blazing Star' (Table 2). For these parameters, Tergitol-TMN-6 at 30 $\mathrm{mL} \cdot \mathrm{L}^{-1}$ was more effective than at $10 \mathrm{~mL} \cdot \mathrm{L}^{-1}$, although differences were not always significant. In all cultivars in Fruitland, the yield of the trees treated with Tergitol-TMN-6 at 10 $\mathrm{mL} \cdot \mathrm{L}^{-1}$ was closer to the targeted yield (yield of hand-thinned control trees) than that at Sunny Slope. One possible reason is that the trees at Sunny Slope were spayed at an earlier stage of blossom, and fertilization conditions were not as favorable compared with those in Fruitland. However, similar to the study in the Sunny Slope orchards, applications at 30 $\mathrm{mL} \cdot \mathrm{L}^{-1}$ caused overthinning. In Fruitland, $\mathrm{CFO}$ at $3 \%$ reduced fruit set in 'Red Globe' but had no effect on fruit size and yield, because all trees were hand-thinned at the time of pit hardening, and fruit-to-fruit competition was reduced.

Applications of CFO or Tergitol-TMN-6 even at the highest rate $\left(30 \mathrm{~mL} \cdot \mathrm{L}^{-1}\right)$, in either

Table 1. Effects of Tergitol-TMN-6 blossom thinner on fruit set, weight, russeting, and yield in 'Elberta' and 'August Lady' in Sunny Slope, Idaho, during the 2003 season. ${ }^{\text {zyx }}$

\begin{tabular}{|c|c|c|c|c|c|c|c|c|}
\hline \multirow[b]{2}{*}{ Treatment } & \multicolumn{2}{|c|}{ Fruit set, fruit $/ \mathrm{cm}^{2}$} & \multicolumn{2}{|c|}{ Fruit weight, $\mathrm{g}$} & \multicolumn{2}{|c|}{ Fruit russeting, $\%$} & \multicolumn{2}{|c|}{ Yield (kg/tree) } \\
\hline & Elberta & August Lady & Elberta & August Lady & Elberta & August Lady & Elberta & August Lady \\
\hline Tergitol $5 \mathrm{~mL} \cdot \mathrm{L}^{-1}$ & $2.12 \mathrm{~b}$ & $1.39 \mathrm{~b}$ & $108.3 \mathrm{c}$ & $93.6 \mathrm{~b}$ & $5.8 \mathrm{a}$ & $10.0 \mathrm{a}$ & $69.3 \mathrm{a}$ & $27.8 \mathrm{ab}$ \\
\hline Tergitol $20 \mathrm{~mL} \cdot \mathrm{L}^{-1}$ & $0.01 \mathrm{~d}$ & $0.05 \mathrm{c}$ & $153.8 \mathrm{a}$ & $151.0 \mathrm{a}$ & $16.2 \mathrm{a}$ & $16.7 \mathrm{a}$ & $2.3 \mathrm{c}$ & $0.67 \mathrm{~d}$ \\
\hline Tergitol $30 \mathrm{~mL} \cdot \mathrm{L}^{-1}$ & $0.001 \mathrm{~d}$ & $0.004 \mathrm{c}$ & $147.9 \mathrm{ab}$ & $100.1 \mathrm{~b}$ & $5.0 \mathrm{a}$ & $11.1 \mathrm{a}$ & $0.63 \mathrm{c}$ & $0.20 \mathrm{~d}$ \\
\hline Crocker's Fish Oil $30 \mathrm{~mL} \cdot \mathrm{L}^{-1}$ & $2.40 \mathrm{~b}$ & $2.43 \mathrm{a}$ & $94.8 \mathrm{c}$ & $98.5 \mathrm{~b}$ & $10.8 \mathrm{a}$ & $6.7 \mathrm{a}$ & $66.6 \mathrm{a}$ & $16.7 \mathrm{bc}$ \\
\hline
\end{tabular}

${ }^{\mathrm{z}}$ Mean separation within columns by LSD at 0.05 . Each value is a mean of three blocks, each with eight trees.

''lberta' peaches were at $70 \%$ to $75 \%$ bloom and those in 'August Lady' were at $80 \%$ bloom at the time of application.

${ }^{x}$ All applications were made at a rate of $1870.8 \mathrm{~L} \cdot \mathrm{ha}^{-1}$.

Table 2. Effects of Tergitol-TMN-6 blossom thinner on fruit set, weight, yield, and russeting in different peach cultivars in commercial orchards in Fruitland, Idaho, during the 2003 season. ${ }^{\text {zyx }}$

\begin{tabular}{|c|c|c|c|c|c|c|c|c|c|}
\hline \multirow[b]{2}{*}{ Treatment } & \multicolumn{3}{|c|}{ Fruit set, fruit $/ \mathrm{cm}^{2}$} & \multicolumn{3}{|c|}{ Fruit weight, $\mathrm{g}$} & \multicolumn{3}{|c|}{ Yield, kg/tree } \\
\hline & Red Globe & Red Haven & Blazing Star & Red Globe & Red Haven & Blazing Star & Red Globe & Red Haven & Blazing Star \\
\hline Control & $2.84 \mathrm{a}$ & $2.20 \mathrm{a}$ & $2.88 \mathrm{a}$ & $147.5 \mathrm{~b}$ & $170.5 \mathrm{c}$ & $159.9 \mathrm{a}$ & $43.5 \mathrm{a}$ & $21.8 \mathrm{a}$ & $23.2 \mathrm{a}$ \\
\hline Tergitol $10 \mathrm{~mL} \cdot \mathrm{L}^{-1}$ & $0.93 \mathrm{c}$ & $0.55 \mathrm{~b}$ & $0.84 \mathrm{~b}$ & $174.8 \mathrm{~b}$ & $222.8 \mathrm{~b}$ & $171.4 \mathrm{a}$ & $32.6 \mathrm{~b}$ & $16.7 \mathrm{~b}$ & $18.1 \mathrm{~b}$ \\
\hline Tergitol $30 \mathrm{~mL} \cdot \mathrm{L}^{-1}$ & $0.24 \mathrm{c}$ & $0.02 \mathrm{~b}$ & $0.16 \mathrm{c}$ & $239.0 \mathrm{a}$ & $261.3 \mathrm{a}$ & $185.0 \mathrm{a}$ & $13.1 \mathrm{c}$ & $2.61 \mathrm{c}$ & $5.1 \mathrm{c}$ \\
\hline Fish Oil $30 \mathrm{~mL} \cdot \mathrm{L}^{-1}$ & $1.85 \mathrm{~b}$ & - & - & $178.0 \mathrm{~b}$ & - & - & $40.6 \mathrm{ab}$ & - & - \\
\hline
\end{tabular}

${ }^{\mathrm{z}}$ Mean separation within columns by LSD at 0.05 . Each value is the mean of three blocks, each with eight trees.

${ }^{y}$ Stages of bloom for each cultivar was 'Red Globe' at 83\% bloom, 'Redhaven' at 85\% bloom, and 'Blazing Star' at 90\% bloom.

${ }^{\mathrm{x}}$ All applications were made at a rate of $1870.8 \mathrm{~L} \cdot \mathrm{ha}^{-1}$. 
the Sunny Slope or Fruitland locations, did not have any adverse effects on fruit set or vegetative growth during the following year (data not shown).

\section{Experiments in 2004}

Tergitol-TMN-6 at $5 \mathrm{~mL} \cdot \mathrm{L}^{-1}$ or more, applied at either $935.4 \mathrm{~L} \cdot \mathrm{ha}^{-1}$ or 1870.8 $\mathrm{L} \cdot \mathrm{ha}^{-1}$ spray volume, significantly reduced fruit set in 'August Lady' peach (Table 3). There was no difference in fruit set between Tergitol-TMN-6 at the $7.5 \mathrm{~mL} \cdot \mathrm{L}^{-1}$ and 10 $\mathrm{mL} \cdot \mathrm{L}^{-1}$ rates; however, both of these rates had significantly greater effect on reduction of fruit set in 'August Lady' peach than did 5 $\mathrm{mL} \cdot \mathrm{L}^{-1}$. Orthogonal contrast analysis revealed that application of Tergitol-TMN-6 at a spray volume of $1870.8 \mathrm{~L} \cdot \mathrm{ha}^{-1}$ was more effective in fruit set reduction of 'August Lady' peach than at $935.4 \mathrm{~L} \cdot \mathrm{ha}{ }^{-1}$. Fruit size and yield of 'August Lady' peach were unaffected by any of the treatments. There was no interaction between rate of TergitolTMN-6 and spray volume for any of the measurements. Tergitol-TMN-6 at 7.5 or 10

Table 3. Effects of Tergitol-TMN-6 blossom thinner on fruit set, weight, and yield of 'August Lady' and 'Zee Lady' peaches in Sunny Slope, Idaho, in 2004. ${ }^{\text {zy }}$

\begin{tabular}{|c|c|c|c|c|c|c|}
\hline \multirow[b]{2}{*}{ Analysis of treatments } & \multicolumn{2}{|c|}{ Fruit set, fruit $/ \mathrm{cm}^{2}$} & \multicolumn{2}{|c|}{ Fruit weight, g } & \multicolumn{2}{|c|}{ Yield, kg/tree } \\
\hline & $\begin{array}{l}\text { August } \\
\text { Lady }\end{array}$ & $\begin{array}{l}\text { Zee } \\
\text { Lady }\end{array}$ & $\begin{array}{l}\text { August } \\
\text { Lady }\end{array}$ & $\begin{array}{l}\text { Zee } \\
\text { Lady }\end{array}$ & $\begin{array}{l}\text { August } \\
\text { Lady }\end{array}$ & $\begin{array}{l}\text { Zee } \\
\text { Lady }\end{array}$ \\
\hline \multicolumn{7}{|l|}{ Treatments } \\
\hline Control & $54.3 \mathrm{a}$ & $43.6 \mathrm{a}$ & $146.2 \mathrm{a}$ & $142.9 \mathrm{a}$ & $74.2 \mathrm{a}$ & $63.7 \mathrm{ab}$ \\
\hline Tergitol $5 \mathrm{~mL} \cdot \mathrm{L}^{-1}$ at $1870.8 \mathrm{~L} \cdot \mathrm{ha}^{-1}$ & $40.4 \mathrm{~b}$ & $37.0 \mathrm{ab}$ & $160.5 \mathrm{a}$ & $152.9 \mathrm{a}$ & $61.3 \mathrm{a}$ & $80.8 \mathrm{a}$ \\
\hline Tergitol $7.5 \mathrm{~mL} \cdot \mathrm{L}^{-1}$ at $1870.8 \mathrm{~L} \cdot \mathrm{ha}^{-1}$ & $26.6 \mathrm{c}$ & $31.1 \mathrm{~b}$ & $163.6 \mathrm{a}$ & $156.9 \mathrm{a}$ & $57.6 \mathrm{a}$ & $63.5 \mathrm{ab}$ \\
\hline Tergitol $10 \mathrm{~mL} \cdot \mathrm{L}^{-1}$ at $1870.8 \mathrm{~L} \cdot \mathrm{ha}^{-1}$ & $25.4 \mathrm{c}$ & $23.2 \mathrm{c}$ & $163.5 \mathrm{a}$ & $144.3 \mathrm{a}$ & $57.7 \mathrm{a}$ & $48.4 \mathrm{~b}$ \\
\hline Tergitol $5 \mathrm{~mL} \cdot \mathrm{L}^{-1}$ at $935.4 \mathrm{~L} \cdot \mathrm{ha}^{-1}$ & $42.7 \mathrm{~b}$ & - & $137.9 \mathrm{a}$ & - & $48.2 \mathrm{a}$ & - \\
\hline Tergitol $7.5 \mathrm{~mL} \cdot \mathrm{L}^{-1}$ at $935.4 \mathrm{~L} \cdot \mathrm{ha}^{-1}$ & $31.9 \mathrm{c}$ & - & $150.5 \mathrm{a}$ & - & $62.6 \mathrm{a}$ & - \\
\hline Tergitol $10 \mathrm{~mL} \cdot \mathrm{L}^{-1}$ at $935.4 \mathrm{~L} \cdot \mathrm{ha}^{-1}$ & $29.4 \mathrm{c}$ & - & $139.4 \mathrm{a}$ & - & $64.8 \mathrm{a}$ & - \\
\hline \multicolumn{7}{|l|}{ Factorial arrangement, orthogonal contrast } \\
\hline $5 \mathrm{~mL} \cdot \mathrm{L}^{-1}$ vs. $7.5 \mathrm{~mL} \cdot \mathrm{L}^{-1}$ Tergitol rate & $* *$ & - & NS & & NS & \\
\hline $5 \mathrm{~mL} \cdot \mathrm{L}^{-1}$ vs. $1 \mathrm{~mL} \cdot \mathrm{L}^{-1}$ Tergitol rate & ** & - & NS & & NS & \\
\hline $7.5 \mathrm{~mL} \cdot \mathrm{L}^{-1}$ vs. $1 \mathrm{~mL} \cdot \mathrm{L}^{-1}$ Tergitol rate & NS & - & NS & & NS & \\
\hline $\begin{array}{l}935.4 \mathrm{~L} \cdot \mathrm{ha}^{-1} \text { vs. } 1870.8 \mathrm{~L} \cdot \mathrm{ha}^{-1} \text { spray volume } \\
\text { Interaction }\end{array}$ & $*$ & - & NS & & NS & \\
\hline Tergitol rate $\times$ spray volume & NS & - & NS & & NS & \\
\hline
\end{tabular}

${ }^{\mathrm{z}}$ Mean separation within columns by LSD at 0.05 .

'Trees were at $85 \%$ bloom in 'August Lady' and in $75 \%$ bloom in 'Zee Lady' at the time of application.

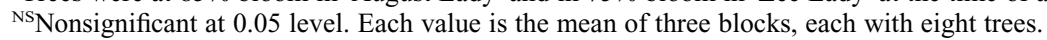

$\mathrm{mL} \cdot \mathrm{L}^{-1}$. In 'Snow Giant' peach, TergitolTMN-6 at $12.5 \mathrm{~mL} \cdot \mathrm{L}^{-1}$ was the only rate that reduced fruit set and yield. Other rates of Tergitol-TMN-6 were ineffective in reducing fruit set in 'Snow Giant', perhaps because this cultivar was sprayed when blooms were in a more advanced stage ( $85 \%$ bloom) and were more fertilized compared with 'Zee Lady', which was at $75 \%$ at the time of application. Fruit color and rate of russeting were unaffected by any rate of TergitolTMN-6 in 'Snow Giant' peach (data not shown).

Tergitol-TMN-6 at $7.5 \mathrm{~mL} \cdot \mathrm{L}^{-1}$ or 10 $\mathrm{mL} \cdot \mathrm{L}^{-1}$, applied either once at about $80 \%$ to $85 \%$ bloom or twice-once at $35 \%$ bloom and again at $80 \%$ to $85 \%$ bloom-reduced fruit set in 'July Red' nectarine in 2005 (Table 6). However, analysis of all treatments (including control) together or in a orthogonal contrast analysis of just Tergitol-TMN-6 treatments as a factorial arrangement revealed that double applications of TergitolTMN-6 at either $7.5 \mathrm{~mL} \cdot \mathrm{L}^{-1}$ or $10 \mathrm{~mL} \cdot \mathrm{L}^{-1}$ resulted in significantly lower fruit set compared with a single application in 'July Red' nectarine. A double application of CFO and lime sulfur did not affect fruit set. In this nectarine, fruit size increased proportionally to the rate and frequency of Tergitol-TMN-6 applications. Yield (Table 6) and fruit color (data not shown) were unaffected by any of the blossom-thinning treatments in 'July Red' nectarine. This is because all trees were hand thinned at the beginning of pit hardening, and the increase in the fruit size between the times of bloom and hand thinning compensated for the reduction in the number of fruits in the trees treated with Tergitol-TMN-6. Tergitol-TMN-6 treatments did not increase severity of nectarine fruit russeting, while reducing the fruit set (Table 6) and needs for hand thinning and labor cost (data not shown). This is an extremely important finding for the nectarine fruit industry, because nectarine fruits are readily russetted by a large number of chemicals, insects, and environmental factors. There was no interaction

Table 4. Effect of Tergitol-TMN-6 on fruit set and return in 'Empress' plum in 2004. ${ }^{\text {zy }}$

\begin{tabular}{|c|c|c|c|c|}
\hline Treatment & Orchard 1 fruit set, fruit $/ \mathrm{cm}^{2}$ & Orchard 1 fruit weight, $g$ & Orchard 2 US no. $1, \%$ & Orchard 2 return, \$US/bin \\
\hline Control & $28.9 \mathrm{a}$ & $156.7 \mathrm{~b}$ & 14.6 & 163.73 \\
\hline Tergitol $10 \mathrm{~mL} \cdot \mathrm{L}^{-1}$ at $1870.8 \mathrm{~L} \cdot \mathrm{ha}^{-1}$ & $7.5 \mathrm{~b}$ & $207.1 \mathrm{a}$ & 44.7 & 233.77 \\
\hline Tergitol $12.5 \mathrm{~mL} \cdot \mathrm{L}^{-1}$ at $1870.8 \mathrm{~L} \cdot \mathrm{ha}^{-1}$ & $7.2 \mathrm{~b}$ & $192.7 \mathrm{a}$ & 41.1 & 223.23 \\
\hline
\end{tabular}

${ }^{2}$ Mean separation within columns by LSD at 0.05 . Each value is the mean of three blocks, each with eight trees.

${ }^{\mathrm{y}}$ Trees were at $75 \%$ to $80 \%$ bloom at the time of applications. US no. 1 refers to high-quality fruits. Each bin of plum is about $400 \mathrm{~kg}$. $\$ \mathrm{US} / \mathrm{bin}$ is the net amount per bin that was paid to the grower by the packing house.

Table 5. Effect of Tergitol-TMN-6 application on fruit set, weight, and yield of 'Zee Lady' and 'Snow Giant' peaches at the University of Idaho Pomology orchards in 2005. ${ }^{\mathrm{yyx}}$

\begin{tabular}{|c|c|c|c|c|c|c|}
\hline \multirow[b]{2}{*}{ Treatment } & \multicolumn{2}{|c|}{ Fruit set, fruit $/ \mathrm{cm}^{2}$} & \multicolumn{2}{|c|}{$\begin{array}{c}\text { Fruit weight, } \mathrm{g} \\
\end{array}$} & \multicolumn{2}{|c|}{$\begin{array}{l}\text { Yield, } \mathrm{kg} / \text { tree } \\
\end{array}$} \\
\hline & Zee Lady & Snow Giant & Zee Lady & Snow Giant & Zee Lady & Snow Giant \\
\hline Tergitol $7.5 \mathrm{~mL} \cdot \mathrm{L}^{-1}$ & $22.0 \mathrm{~b}$ & $29.5 \mathrm{a}$ & $209.2 \mathrm{a}$ & $273.2 \mathrm{a}$ & $14.6 \mathrm{ab}$ & $14.5 \mathrm{a}$ \\
\hline
\end{tabular}

${ }^{\mathrm{z}}$ Mean separation within columns by LSD at 0.05 . Trees in all treatments, including control, were hand thinned after fruit set calculation. Trees in 'Zee Lady' were at $75 \%$ bloom and those in 'Snow Giant' were in $85 \%$ bloom at the time of application.

${ }^{\mathrm{y}} \mathrm{All}$ applications were made at a rate of $1870.8 \mathrm{~L} \cdot \mathrm{ha}^{-1}$.

x'Zee Lady' was at $75 \%$ bloom and 'Snow Giant' was at $85 \%$ bloom at the time of application. 
Table 6. Effects of Tergitol on 'July Red' nectarine fruit set, weight, russeting, and yield in $2005{ }^{\text {zy }}$

\begin{tabular}{|c|c|c|c|c|}
\hline Analysis of treatments & $\begin{array}{l}\text { Fruit } \\
\text { set, } \%\end{array}$ & $\begin{array}{c}\text { Fruit } \\
\text { weight, } g\end{array}$ & $\begin{array}{l}\text { Russeting, } \\
\%\end{array}$ & $\begin{array}{l}\text { Yield, } \\
\mathrm{kg} / \text { tree }\end{array}$ \\
\hline \multicolumn{5}{|l|}{ Treatment } \\
\hline Control $^{\mathrm{z}}$ & $45.6 \mathrm{a}$ & $147.5 \mathrm{c}$ & $10.1 \mathrm{a}$ & $99.9 \mathrm{a}$ \\
\hline Tergitol $7.5 \mathrm{~mL} \cdot \mathrm{L}^{-1}$ once at $80 \%$ to $85 \%$ bloom & $29.8 \mathrm{~b}$ & $195.7 \mathrm{ab}$ & $14.8 \mathrm{a}$ & $75.7 \mathrm{a}$ \\
\hline Tergitol $10 \mathrm{~mL} \cdot \mathrm{L}^{-1}$ once at $80 \%$ to $85 \%$ bloom & $30.9 \mathrm{~b}$ & $173.5 \mathrm{~b}$ & $9.7 \mathrm{a}$ & $82.4 \mathrm{a}$ \\
\hline Tergitol $7.5 \mathrm{~mL} \cdot \mathrm{L}^{-1}$ at $35 \%$ and $80 \%$ to $85 \%$ bloom & $15.5 \mathrm{c}$ & $206.9 \mathrm{a}$ & $14.9 \mathrm{a}$ & $72.4 \mathrm{a}$ \\
\hline Tergitol $10 \mathrm{~mL} \cdot \mathrm{L}^{-1}$ at $35 \%$ and $80 \%$ to $85 \%$ bloom & $12.3 \mathrm{c}$ & $206.0 \mathrm{a}$ & $14.6 \mathrm{a}$ & $91.3 \mathrm{a}$ \\
\hline $\begin{array}{l}20 \mathrm{~mL} \cdot \mathrm{L}^{-1} \text { lime sulfur and } 20 \mathrm{~mL} \cdot \mathrm{L}^{-1} \mathrm{CFO} \text { at } 35 \% \\
\text { and } 80 \% \text { to } 85 \% \text { bloom }\end{array}$ & $50.4 \mathrm{a}$ & $174.0 \mathrm{~b}$ & $9.6 \mathrm{a}$ & $98.4 \mathrm{a}$ \\
\hline \multicolumn{5}{|l|}{ Factorial arrangement, orthogonal contrast } \\
\hline Tergitol $7.5 \mathrm{~mL} \cdot \mathrm{L}^{-1}$ vs. $10 \mathrm{~mL} \cdot \mathrm{L}^{-1}$ & NS & NS & NS & NS \\
\hline Frequency of application (once vs. twice) & $* *$ & $*$ & NS & NS \\
\hline \multicolumn{5}{|l|}{ Interaction } \\
\hline Tergitol rate $\times$ frequency of application & NS & NS & NS & NS \\
\hline
\end{tabular}

${ }^{\mathrm{z}}$ Mean separation within columns by LSD at 0.05 .

${ }^{\mathrm{y}}$ All applications were made at a rate of $1870.8 \mathrm{~L} \cdot \mathrm{ha}^{-1}$.

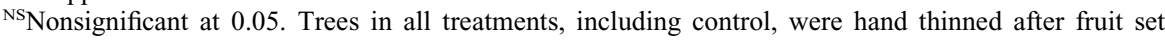
calculation. CFO, Crocker's fish oil. between rate and frequency of application of Tergitol-TMN-6 for fruit set, quality, or yield in nectarine (Table 6).

In Utah orchards, application of TergitolTMN-6 at $10 \mathrm{~mL} \cdot \mathrm{L}^{-1}$ or $12.5 \mathrm{~mL} \cdot \mathrm{L}^{-1}$ reduced fruit set in 'John Henry', 'O'Henry', and 'Angelus' cultivars (Table 7). Although fruit set was reduced proportionally to the Tergitol-TMN-6 concentrations, fruit reduction with $7.5 \mathrm{~mL} \cdot \mathrm{L}^{-1}$ was not significantly different from the control. None of Tergitol-TMN6 treatments in the Utah orchards resulted in reduction of yield compared with control trees.

\section{General comments}

Considering all our results from different regions and different years, we can conclude that the effective rates for Tergitol-TMN-6 for stone fruit blossom thinning is between 5 $\mathrm{mL} \cdot \mathrm{L}^{-1}$ and $12.5 \mathrm{~mL} \cdot \mathrm{L}^{-1}$. It also appears that a spray volume of either $1870.8 \mathrm{~L} \cdot \mathrm{ha}^{-1}$ or 935.4 $\mathrm{L} \cdot \mathrm{ha}^{-1}$ is effective in blossom thinning of peach when using Tergitol-TMN-6, although $1870.8 \mathrm{~L} \cdot \mathrm{ha}^{-1}$ seems to be more effective. Spray volume of blossom thinners can affect fruit set. Time, temperature, bloom developing stages, and varietal differences are very important factors influencing the effectiveness of blossom thinning in peaches. It is essential that blossom thinners be applied when some, but not all, fertilization has taken place. Also, the severity of frost damage must be considered before determining rates of any blossom thinner. In apples, the best time to spray to thin blossoms is when the king bloom is open and fertilized, and only one side bloom is open but not fertilized (Fallahi and Willemsen, 2002). At this stage, the other side blooms are at the "popcorn" stage or

slightly (but not completely) open, and not fertilized. However, because stone fruits do not have king blooms, an arbitrary percentage of blooms should be used as a gauge for timing blossom-thinning applications in these fruits. Based on our experiments, it seems that when about $75 \%$ to $80 \%$ of blooms are open, and when reasonably good pollination and fertilization conditions exist before application, this is an optimum stage for spraying Tergitol-TMN-6. It also seems that higher concentrations of Tergitol-TMN6 are needed when the percentage of open blooms is higher (i.e., $85 \%-100 \%$ ). However, we note that the actual degree of fertilization may vary from orchard to orchard, even if both orchards are at an identical stage of bloom. Therefore, temperature and bee activity should be closely observed and taken into account for timing of blossomthinning spray. Temperature affects bee activity and subsequently the number of fertilized flowers. Temperature also affects the chemical characteristics and the effectiveness of blossom thinners. Further research is needed to find a better method for a quick determination of the proper stage based on physiological development of pollen tube or fertilization of the ovules.

A double application of Tergitol-TMN-6 ( $\sim 35 \%$ and $80 \%$ to $85 \%$ open bloom) was also effective in thinning and seemed to be slightly better than a single application. However, a double application may pose a number of problems and risks. The first potential problem is overthinning, because a sufficient number of flowers may not have been fertilized at the times of application. The second problem is that the span of time for the application of any blossom thinner is

Table 7. Effects of Tergitol on fruit set in different cultivars of peaches in Utah in 2005. ${ }^{\text {zy }}$

\begin{tabular}{lccc}
\hline & \multicolumn{3}{c}{ Fruit set, $\%$} \\
\cline { 2 - 4 } Treatment & John Henry & O'Henry & Angelus \\
\hline Control & $68.0 \mathrm{a}$ & $83.3 \mathrm{a}$ & $56.2 \mathrm{a}$ \\
Tergitol $7.5 \mathrm{~mL} \cdot \mathrm{L}^{-1}$ once at $80 \%$ bloom & $66.8 \mathrm{a}$ & $79.5 \mathrm{ab}$ & $53.1 \mathrm{ab}$ \\
Tergitol $10 \mathrm{~mL} \cdot \mathrm{L}^{-1}$ once at $80 \%$ bloom & $56.0 \mathrm{~b}$ & $72.7 \mathrm{~b}$ & $41.9 \mathrm{~b}$ \\
Tergitol $12.5 \mathrm{~mL} \cdot \mathrm{L}^{-1}$ once at $80 \%$ bloom & $50.1 \mathrm{~b}$ & $71.8 \mathrm{~b}$ & $39.5 \mathrm{~b}$ \\
\hline
\end{tabular}

${ }^{\mathrm{z}}$ Means within columns are separated by LSD at 0.05 .

${ }^{y}$ All applications were made at a rate of $1870.8 \mathrm{~L} \cdot \mathrm{ha}^{-1}$ very limited and it may not be always feasible to apply the thinner twice, particularly in a large commercial setting when several hectares of orchards should be sprayed within a limited time window. Mode of action in some blossom thinners could be more than just being caustic, and each variety could react differently to blossom thinners in each region. For example, Wilkins and associates (2004) reported that the application of Tergitol-TMN-6 from popcorn to shuck-off stages resulted in good thinning in 'Fireprince' peach, and the efficacy of the chemical applied at full bloom was similar to that at petal fall in Alabama. Certainly at shuck-off, whatever fertilization that is to take place will have taken place. Perhaps, as observed in the study by Byers and Lyons (1985), it was the killing of the peduncle and some other tissue that gave this chemical such a wide window of efficacy in the study by Wilkins and colleagues (2004). However, in our study we noticed that application of TergitolTMN-6 at an earlier stage of bloom (i.e., less percentage of blooms open) was more effective than late application. This contradiction suggests that the mode of action of TergitolTMN-6 could interact with varietal and environmental factors.

One should be cautious about fruit marking and leaf burning with the application of any blossom thinner. Slow drying conditions, as well as late applications, increase the possibility of fruit marking and leaf burning. However, in our study, fruit marking was not observed in any location or at any concentration of Tergitol-TMN-6 in stone fruit. Leaf burning is often associated with blossomthinning applications (Fallahi and Willemsen, 2002). Although Tergitol-TMN-6 induced varying degrees of leaf and foliage burning, even the most severe symptoms disappeared after a few weeks, and did not cause any adverse effect on the following year's crop. Also, because fruit size at harvest was not adversely affected with the application of Tergitol-TMN-6 in the range of 5 to 12.5 $\mathrm{mL} \cdot \mathrm{L}^{-1}$, it is doubtful if the overall photosynthetic capacity of the whole tree is diminished over a long time with this chemical.

Because trees in all treatments were hand thinned after fruits were counted for fruit set calculations, yield and quality differences at harvest were not always significant. However, the earlier thinning of flowers resulted in production of larger fruits in some Tergitol-TMN-6 treatments. That is because fruitto-fruit competition in the trees receiving some Tergitol-TMN-6 treatments was reduced several weeks before the time that the control trees were thinned. Thus, in addition to the major reduction in the cost of hand thinning, fruit size at harvest, in some cases, may increase with the use of TergitolTMN-6. The larger fruit size in these cases often compensated for the fewer fruits, resulting in a similar yield to the control trees that had only hand thinning several weeks after bloom

Currently we are cooperating with several researchers on evaluating Tergitol-TMN-6 in 
different states and regions. The results presented here have been a valuable basis for these studies, and we think that TergitolTMN-6 may have the potential to become a reliable blossom thinner for stone fruits after more regional tests and registration.

\section{Literature Cited}

Byers, R.E. and C.G. Lyons Jr. 1985. Peach flower thinning and possible sites of action of desiccating chemicals. J. Amer. Soc. Hort. Sci. 110:662-667.

Fallahi, E. 1997. Application of Endothallic acid, pelargonic acid, and hydrogen cyanamide for blossom thinning in apple and peach. Horttechnology 7:395-399.

Fallahi, E. 1998. The use of blossom thinners for regular cropping of deciduous fruit trees. Proc. Plant Growth Regulation Society of America. 27-33.
Fallahi, E., M. Kilby, and J.W. Moon. 1990. Effects of various chemicals on dormancy, maturity and thinning of peaches. Deciduous fruit and nut. University of Arizona, College of AgriRpt. Ser P-83:121-128.

Fallahi, E., R.R. Lee, and G.A. Lee. 1998. Commercial-scale use of hydrogen cyanamide for blossom thinning of apple and peach. Horttechnology 8:556-560.

Fallahi, E., B.R. Simons, J.K. Fellman, and W.M. Colt. 1992. Use of hydrogen cyanamide for apple and plum thinning. Plant Growth Regulat. 11:435-439.

Fallahi, E. and K. Willemsen. 2002. Blossom thinning of pome and stone fruit. HortScience 37:474-476.

Fallahi, E., M.W. Williams, and W.M. Colt. 1997. Blossom thinning of 'Law Rome Beauty' apple with hydrogen cyanamide and monocarbamide dihydrogensulfate. J. Tree Fruit Prod. 2:33-44.

Greene, D.W., K.I. Hauschild, and J. Krupa. 2001. Effect of blossom thinners on fruit set and fruit size of peaches. Horttechnology 11: 179-183.

Hildebrand, E.M. 1944. The mode of action of the pollenicide. Elgetol. Proc. Amer. Soc. Hort. Sci. 45:53-58.

Southwick, S.M., K.G. Weis, J.T. Yeager, and M.E. Rupert. 1998. Blossom thinning of 'Loadel' cling peach with a surfactant: Effects of concentration, carrier volume, and differential applications within the canopy. Horttechnology 8:55-58.

Warner, G. 1998. Consistent tonnage needed for profitability. Good Fruit Grower 49:9-10.

Whiting, M.D., D. Ophardt, and J.R. McFerson. 2006. Chemical blossom thinners vary in their effect on sweet cherry fruit set, yield, fruit quality, and crop value. Horttechnology 16:6670.

Wilkins, B.S., R.C. Ebel, W.A. Dozier, J. Pitts, and R. Boozer. 2004. Tergitol-TMN-6 for thinning peach blossoms. HortScience 39:16111613 . 